\title{
Air Transportation Workers
}

National Cancer Institute

\section{Source}

National Cancer Institute. Air Transportation Workers. NCI Thesaurus. Code C122422.

Workers involved with the transportation of passengers and/or cargo using aircraft. This includes aircraft mechanics and service technicians; airline pilots, copilots, and flight eng ineers; cargo and freight agents; and reservation and transportation ticket agents and travel clerks. 